\title{
Solubilization of insoluble potassium and phosphate by Paenibacillus kribensis CX-7: A soil microorganism with biological control potential
}

\author{
Ai-min Zhang ${ }^{1,2 *}$, Gang-yong Zhao', Tong-guo Gao ${ }^{2}$, Wen Wang ${ }^{2}, \mathrm{Jia} \mathrm{Li}^{2}$, Shuang-feng Zhang ${ }^{1}$, \\ and Bao-cheng $\mathrm{Zhu}^{2}$ \\ ${ }^{1}$ Biological Technology Center of Hebei University, Baoding, China. \\ ${ }^{2}$ College of Life Science, Agricultural University of Hebei, Baoding, 071001 China.
}

Accepted 19 December, 2012

\begin{abstract}
From wheat field soil samples of Chang'an, Shanxi, seven multifunctional strains with the ability of solubilizing phosphate and potassium were isolated for its utilization as a biological fertilizer, and the most efficient strain named CX-7 was chosen for further study. CX-7 was identified as Paenibacillus kribbensis after a series of physiological and biochemical experiments, morphological observation and 16S rRNA gene sequence analysis. The solubilization ability of CX-7 was tested in the condition of pure culture. The results show that $71.60 \mathrm{mg} / \mathrm{L}$ and $5.18 \mathrm{mg} / \mathrm{L}$ water-soluble phosphorus and $3.44 \mathrm{mg} / \mathrm{L}$ potassium can be released from phosphate powder, lecithin and potassium feldspar powder, respectively which means that CX-7 had the high degradation rate on inorganic phosphorus. Antagonistic experiment showed that CX-7 strain had widely antagonism against pathogenic microorganism (cotton yellow wilt pathogen, cotton wilt pathogen, wheat root rot diseases pathogen, wheat scab pathogens and Pestalotiopsis microspora). This suggests that the stain has potential for further evaluation for its use as a biological fertilizer and biological control regent.
\end{abstract}

Key words: Paenibacillus kribbensis, phosphate solubilization, potassium solubilization, biological control regent.

\section{INTRODUCTION}

Silicate bacteria have the ability of decomposing soil potassium minerals, activate potassium for the absorption and utilization of plant, and increasing crop yield (Sun and Zhang, 2006; Tang and Zhang, 2008; Xu et al., 2007; Sheng et al., 2001). Paenibacillus kribbensis is one kind of silicate bacteria, which has the effect of potassium and phosphate-solubilization and nitrogen-fixing, so it is widely used in agricultural production in China (Zhang and Zuo, 2000).

*Corresponding author: E-mail: zhangam2008@yahoo.com.cn. Tel: 008613803269908. Fax: 0086-312-5079734.
In 1993, the genus Paenibacillus was defined after an extensive analysis of $16 \mathrm{~S}$ rRNA gene sequences of 51 species of the genus Bacillus (Ash et al. 1993). Paenibacillus is widely distributed in the environment and almost all the strains have one important characteristic, which is the ability against broad spectrum microorganisms by its secondary metabolites (Alvarez et al., 2006). P. kribbensis has been used widely and the majority scholars generally believe that $P$. kribbensis is a specific type of the silicate bacteria (Ross et al., 2001). $P$. kribbensis grows well on nitrogen-free medium including potassium feldspar, indicating its ability of nitrogen fixation and decomposition of the mineral potassium (Jing and $\mathrm{Xu}$, 1997). Many papers about its ability of phosphate and 
potassium solubilization have been published all over the world, but it not widely used in agriculture for its non satisfied ability on solubilization of phosphate and potassium.

Soil is the basis for crop production. It can provide mechanical support, water and oxygen, and provide the necessary nutritional elements for crop. Soil microorganisms also play an important role in the decomposition of soil organic matter and subsequent nutrient release (Han et al., 2011). Plant pathogen is one kind of microorganism, which could decrease the yield of crop. Biological control is a kind of methods to decrease the amount of plant pathogen, and inhibit its growth in order to alleviate the plant disease by one or more microorganism or its metabolite (Alvarez et al., 2006). It can prevent disease and promote growth by the interaction between plant, pathogen, biological control bacteria, the surface of plant, and beneficial microorganism and natural environment (Aperce et al., 2010).

With the purpose of screening the efficient strains which could solubilize phosphate/potassium and have the ability of biological control, the bacteria which can break down the mineral containing the elements of phosphorus and potassium simultaneously for supplying the crop nutrients were separated and further study was carried out on its ability as anti-pathogen. So, the theoretical basis for large-scale application of the multifunctional $P$. kribbensis can be gotten.

In this field, many researches have been done to resolve the mechanism of releasing potassium and phosphorus (Podgorskii et al., 1988; Welch et al., 1999; Welch and Ullman, 1993). Other work was done to discover many microorganisms having the ability for biological control (Peypoux et al., 1984; Rosado and Seldin, 1993; Seldin and Alviano, 2010) but the multifunctional strains have seldom been reported.

\section{MATERIALS AND METHODS}

\section{Soil sample, strains and isolation medium}

The wheat soil of Chang'an, Shanxi Province was collected. The topsoil was removed with a small shovel and soil samples at a depth of $5-10 \mathrm{~cm}$ were chosen. Isolation medium [sucrose $5.0 \mathrm{~g} / \mathrm{L}$, FeC13 (1\%) several drops, $\mathrm{Na}_{2} \mathrm{HPO}_{4} 2.0 \mathrm{~g} / \mathrm{L}, \mathrm{MgSO}_{4} \cdot 7 \mathrm{H}_{2} \mathrm{O} 0.5 \mathrm{~g} / \mathrm{L}$, potassium feldspar powder (160-180 mesh) $1.0 \mathrm{~g} / \mathrm{L}$, agar $20.0 \mathrm{~g} / \mathrm{L}$ ] was used as isolation medium in this study to separate bacteria. Bacillus mucilaginosus AC10012 (Culture preservation center of Chinese Academy of Agricultural Sciences) was used as the control in the solubilization of phosphate and potassium experiment.

\section{Isolation of strain}

Under sterile conditions, $5 \mathrm{~g}$ soil was taken and suspended in $45 \mathrm{~mL}$ sterilized water, shaken for $10 \mathrm{~min}$, heated to $80^{\circ} \mathrm{C}$ with water bath for $3 \mathrm{~min}$, and finally spread on the plate of isolation medium after a series of dilution. The plates were then cultured for 3-5 days at $28-3^{\circ} \mathrm{C}$. Colonies which had hydrolytic ring were chosen with inoculating needle. Solubilizing phosphate and potassium, screening and purification experiments was done to choose the strain which has the most efficient solubilizing phosphate and potassium ability. We named the strain CX-7 (Bizani and Brandcli, 2012).

\section{Identification of CX-7 strain}

Physiological and biochemical tests including catalase test, nitrate reduction test, starch hydrolysis test, V-P reaction, citrate use test, glucose oxidation fermentation test, methyl red test, indole test, gelatin liquefaction test and heat resistance tests, etc. were done according to Bergey's manual of systematic bacterioly (Buchanan et al., 1974) and The Manual of Determination Bacteriology (Dong and Cai, 2001). Cell morphology and colony morphology of the separated strains were also observed. 16S rRNA gene sequence of CX-7 was analyzed according to the following step: total DNA was extracted from strain CX-7 by the method described in Seldin and Dubnau (1985). The procedure described by Massol-Deya et al. (1995) was employed for PCR amplification of the 16S rRNA gene. The positive primer was 27F as 5'-AGAGTTTGATCCTGGCTCAG-3' and the reverse primer was 1495R as 5'-CTACGGCTACCTTGTTACGA-3'. The amplification condition was 30 cycles of $94^{\circ} \mathrm{C}(3 \mathrm{~min}), 94^{\circ} \mathrm{C}(1 \mathrm{~min}), 55^{\circ} \mathrm{C}(1 \mathrm{~min})$ and $72^{\circ} \mathrm{C}$ (3 min).

\section{Phosphate-solubilizing experiment}

The Olsen and Sommers method (1982) was used to measure the available phosphorus. Standard curve was drawn with: 0.0, 1.0, 2.0, $3.0,4.0,5.0 \mathrm{~mL}$ and $5.0 \mathrm{mg} / \mathrm{L} \mathrm{KH}_{2} \mathrm{PO}_{4}$ aspiration was taken to 50 $\mathrm{mL}$ volumetric flask respectively. Then, $10 \mathrm{~mL} 0.5 \mathrm{~mol} / \mathrm{L} \mathrm{NaHCO}$ and $30 \mathrm{~mL}$ distilled water were added in each flask and shaken well. At last, $5.0 \mathrm{~mL}$ molybdenum antimony anti-reagent was added and color reaction was done. OD data were determined using colorimetric analysis at $720 \mathrm{~nm}$ with spectrophotometer. The standard curve was drawn with phosphorus content as ordinate against OD date as abscissa.

CX-7 strain was cultured as: One transferred loop seed from CX-7 strain slope and AC10012 strain slope was inoculated in $250 \mathrm{~mL}$ flake containing $50 \mathrm{~mL}$ seed media $(0.5 \mathrm{~g}$ beef extract, $10.0 \mathrm{~g}$ peptone, $5.0 \mathrm{~g} \mathrm{NaCl}, 15-20 \mathrm{~g}$ agar, $1000 \mathrm{~mL}$ water, at $\mathrm{pH}$ 7.2-7.4). Strains were cultured at the condition of $30^{\circ} \mathrm{C}, 180 \mathrm{r} / \mathrm{min}$ of rotation speed for $12 \mathrm{~h}$. Then, $1 \mathrm{~mL}$ seed culture was inoculated to $250 \mathrm{~mL}$ flake containing $50 \mathrm{~mL}$ phosphate solubilization media $[0.5 \mathrm{~g}$ $\left(\mathrm{NH}_{4}\right)_{2} \mathrm{SO}_{4}, 5.0 \mathrm{~g}$ sucrose, $10.0 \mathrm{~g}$ soybean cake powder, $0.5 \mathrm{~g}$ $\mathrm{MgSO}_{4}, 0.5 \mathrm{~g}$ yeast extract, $1 \mathrm{~mL} \mathrm{MnSO}_{4}(11 \%), 1 \mathrm{~mL} \mathrm{FeSO} 4(1 \%)$, $10.0 \mathrm{~g}$ rock phosphate powder or $0.2 \mathrm{~g}$ lecithin, and $1000 \mathrm{~mL}$ distilled water]. They were cultured at the condition of $30^{\circ} \mathrm{C}$, and 180 $\mathrm{r} / \mathrm{min}$ of rotation speed for $72 \mathrm{~h}$.

After culturing, the fermentation broth was centrifuged at 4000 $\mathrm{r} / \mathrm{min}$ for $20 \mathrm{~min}$; supernatant fluid was taken and the constant volume was $50 \mathrm{~mL}$. The sediment was ground for $10 \mathrm{~min}$ in the mortar with $1.0 \mathrm{~g}$ quartz sand. The lapping liquid was treated by centrifugation at $4000 \mathrm{r} / \mathrm{min}$ for $20 \mathrm{~min}$; supernatant fluid was taken again and the constant volume was $50 \mathrm{~mL}$. The two times supernatant fluid were mixed together.

Soluble phosphorus was measured using the same methods. 10 $\mathrm{mL}$ mixed supernatant fluid was removed to $150 \mathrm{~mL}$ flake, then 10 $\mathrm{mL} 0.5 \mathrm{~mol} / \mathrm{L} \mathrm{NaHCO}_{3}$ and $35 \mathrm{~mL}$ distilled water was added, at last $5.0 \mathrm{~mL}$ molybdenum antimony anti-reagent was added and color reaction was done. After $10 \mathrm{~min}, \mathrm{OD}$ data of fermentation broth was 


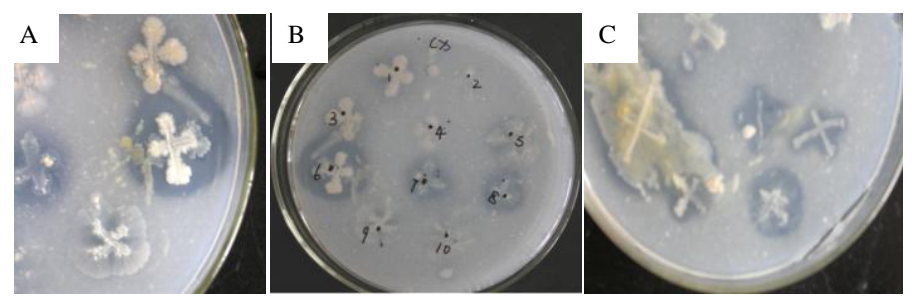

Figure 1. The plates of solubilizing potassium and phosphorus (inorganic and organic). A. Solubilizing potassium ore powder screening plate. B. Solubilizing inorganic phosphorus screening plate. C. Solubilizing organic screening plate phosphorus.

determined using colorimetric analysis at $720 \mathrm{~nm}$ with spectrophotometer and the blank contrast absorption date is 0 . Soluble phosphorus content can be measured by comparing that with the standard curve.

\section{Potassium solubilization experiment}

Standard curve of potassium can be drawn according to sodium-tetraphenylborate methods (Zhang and Zuo, 2000). The procedure was as follow: 0.0, 1.0, 2.0, 4.0, 6.0, 8.0 and $10.0 \mathrm{~mL} 2.0$ $\mathrm{mg} / \mathrm{L} \mathrm{KCl}$ aspiration were taken to $25 \mathrm{~mL}$ volumetric flask. Then, 1.0 $\mathrm{mL}$ formaldehyde-EDTA masking regent and $1 \mathrm{~mL}$ sodium-tetraphenylborate solution were added and shaken well. After $15 \mathrm{~min}$, color reaction was done. OD data were determined using colorimetric analysis at $420 \mathrm{~nm}$ with spectrophotometer. The standard curve was drawn with potassium content as ordinate against OD data as abscissa.

The broth was centrifuged at $4000 \mathrm{r} / \mathrm{min}$ for $20 \mathrm{~min}$; supernatant fluid was taken and $1 \mathrm{~mL}$ formaldehyde-EDTA solution was added. Then, $1 \mathrm{~mL}$ sodium-tetraphenylborate solution was added and shaken well. After $15 \mathrm{~min}$, color reaction was done. OD data were determined using colorimetric analysis at $420 \mathrm{~nm}$ with spectrophotometer and the uninoculated media was the control.

\section{Antagonism experiment}

Pathogenic microorganisms including cotton yellow wilt pathogen, Cotton wilt pathogen, wheat root rot pathogen, wheat scab pathogens and Pestalotiopsis microspora were used in this study, and they are all preserved in the lab of Hebei Academy of Agriculture Sciences, China.

For confrontation test, 5 strains of pathogenic microorganism were inoculated in the PDA media [potato $200.0 \mathrm{~g}$ (potato was peeled, diced and boiled for $30 \mathrm{~min}$, and filtered with gauze), 1000 $\mathrm{mL}$ water, glucose $20.0 \mathrm{~g}$, agar $15-20 \mathrm{~g}$ ] slope. After 7 days, $1 \mathrm{~mL}$ of sterilized water was added to the slope and spore suspension was made. The new $50 \mathrm{ml}$ PDA culture medium was mixed with $1 \mathrm{~mL}$ spore suspension. Then, $20 \mathrm{~mL}$ medium was poured in the culture dish to make plate. For confrontation test, $2.5 \mathrm{~mm}$ hole was perforated in the pathogenic plate. $40 \mu \mathrm{L} \mathrm{CX-7} \mathrm{strain} \mathrm{fermentation}$ broth was poured in the hole, then cultured at $28^{\circ} \mathrm{C}$ for 3 days. The inhibition zone was measured (Simone et al., 2012).

\section{RESULTS AND DISCUSSION}

\section{Isolation of CX-7 strain}

After 3-5 days culturing, seven strains which had the ability of solubilizing phosphate and potassium were separated from the soil sample (Figure 1). Of the seven strains, strain CX-7 had the highest ability of solubilization of phosphate and potassium. According to the ability of solubilization of phosphate and potassium, CX-7 was chosen as the most efficient stain for future study.

\section{Observation of cell morphology and colony morphology}

The colony of CX-7 strain was milky write, round, convex, transparent and viscous and the diameter was 2.0-5.0 mm. The cell was long rod-shaped and the size was 2.5-3.8 $\mu \mathrm{m} \times$ 0.68-0.93 $\mu \mathrm{m}$ (Figure 2).

\section{Physiological and biochemical characteristics of CX-7 strain}

Physiological and biochemical characteristics of $\mathrm{CX}-7$ strain were done according to "Berger's Manual of Systematic Bacteriology", using E. coli as the control strain. The results can be seen in Table 1.

Apart from the above physiological and biochemical characteristics, many growth experiments were done. Strain CX-7 grew optimally at $30-37^{\circ} \mathrm{C}$ and grew optimally between $\mathrm{pH} 6.5$ and 8.0. It grew optimally in the presence of $0-2 \%(\mathrm{w} / \mathrm{v}) \mathrm{NaCl}$. Strain $\mathrm{CX}-7$ grew at $10^{\circ} \mathrm{C}$ and $44^{\circ} \mathrm{C}$, but not at $4^{\circ} \mathrm{C}$ or temperatures above $45^{\circ} \mathrm{C}$. It did not grow in the presence of $5 \%(\mathrm{w} / \mathrm{v}) \mathrm{NaCl}$. All these characters were basically found to have physiological properties that allowed their distinction from Paenibacillus spp.

\section{The phylogenetic tree and the analysis of sequence of CX-7 strain}

By amplification and purification methods, strain CX-7sequence was obtained. The resulting 16S rRNA gene sequence of strain CX-7 (1442 nt) was compared with the 16S rRNA gene sequences (from GenBank 

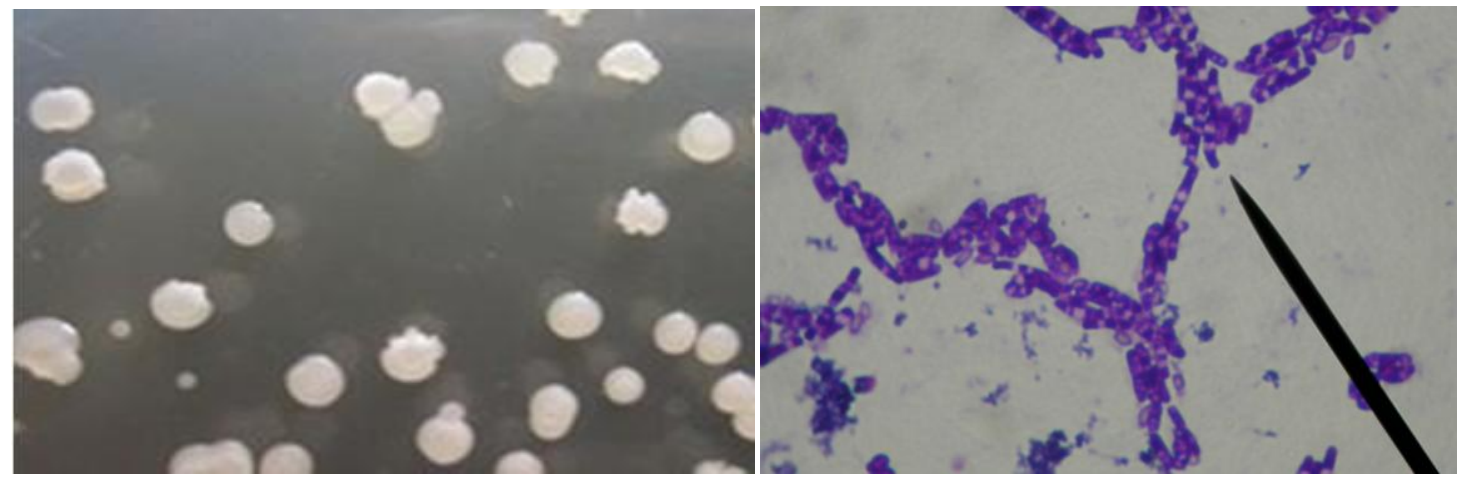

A

Figure 2. Colony morphology and Cell morphology of CX-7 strain. A. Colony morphology of CX-7 strain. B. Cell morphology of CX-7 strain.

Table 1. Physiological and biochemical characteristics of CX-7 strain.

\begin{tabular}{lc}
\hline Experiment name & Strain CX-7 \\
\hline Aerobism test & facultative anaerobic \\
V.P. test & - \\
Nitrate reduction test & + \\
Indole test & + \\
Hydrolysis of starch test & + \\
Catalase test & + \\
Glucose fermentation test & + \\
Mannitol fermentation test & + \\
Xylose fermentation test & + \\
Maltose fermentation test & + \\
Lactose fermentation test & + \\
Sucrose fermentation test & + \\
Fructose fermentation test & + \\
Methyl red test & - \\
Phenylalanine deaminase & - \\
Lecithinase test & - \\
Gelatin liquefaction test & + \\
Utilization of citrate salt & + \\
Hydrolysis of casein test & - \\
Urease test & - \\
\hline
\end{tabular}

+ , representations positive; -, representations negative.

database) using the BLAST program (http://www.ncbi.nlm.nih.gov/blast/) to determine an approximate phylogenetic affiliation; gene sequences were aligned with those of closely related species using CLUSTAL W software (Thompson et al., 1994). Blast software was used for manual editing of the sequences and a phylogenetic tree with 1,000 replicates of bootstrap was constructed using Neighbor-Joining methods (Kumar et al., 2008). The sequence homology was up to $90 \%$ compared with the 16S rRNA sequence from GenBank (Figure 3 ). The phylogenetic tree of the standard strain was constructed.

By colony morphology, bacterial characteristics and determination of physiological and biochemical reaction, according to "Berger's Manual of Systematic Bacteriology", the strain tested was preliminarily identified 


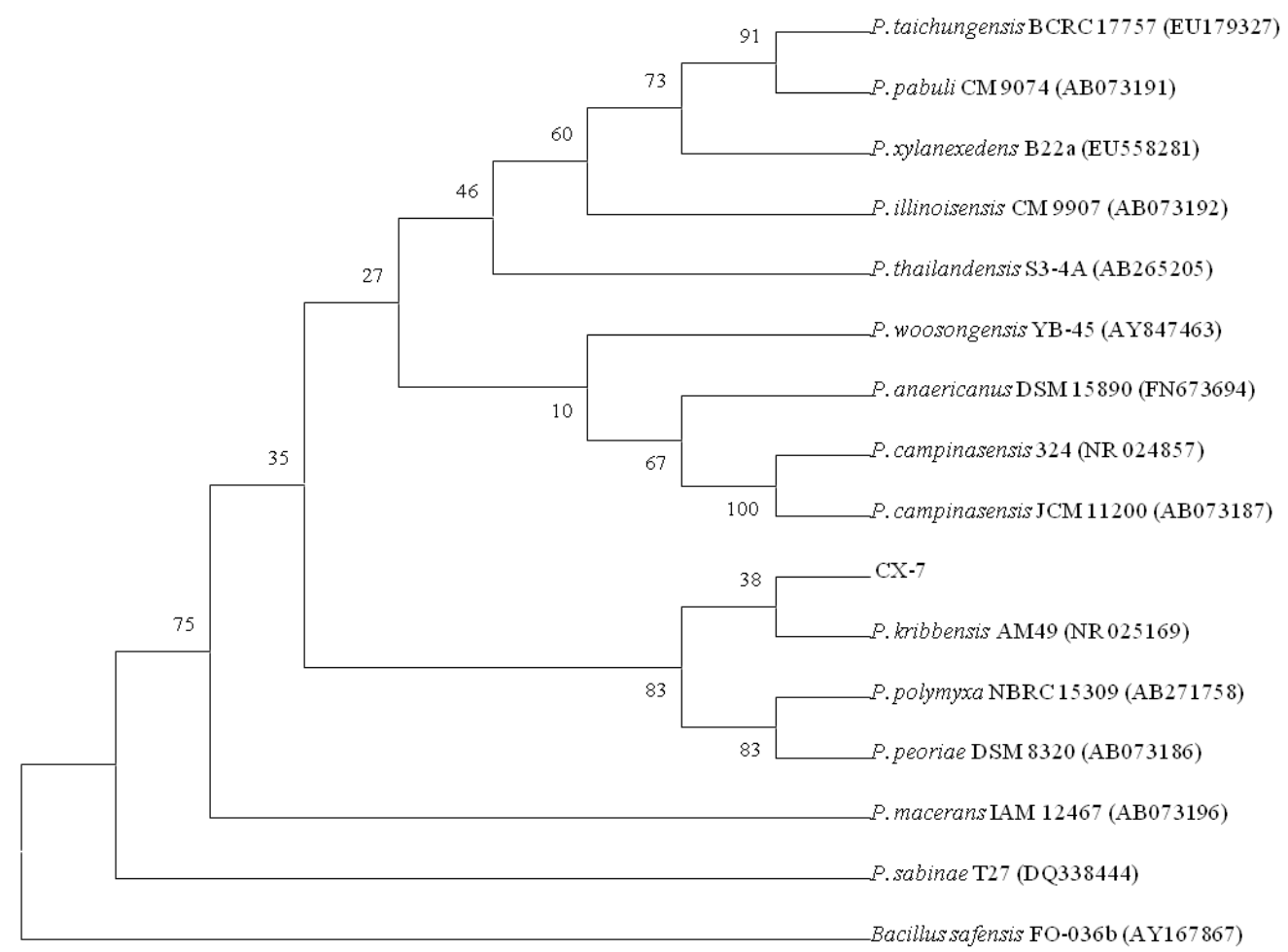

Figure 3. The phylogenetic tree based on 16S rRNA gene sequences showing relationship between CX-7 strain and the standard strains.

Table 2. The ability of phosphorus and potassium solubilization of CX-7 strains.

\begin{tabular}{lcccccc}
\hline \multirow{2}{*}{ Strain } & \multicolumn{2}{c}{ Organic phosphorus } & \multicolumn{2}{c}{ Inorganic phosphorus } & \multicolumn{2}{c}{ Feldspar Powder } \\
\cline { 2 - 7 } & Average OD & Content $\mathbf{~ m g / L}$ & Average OD & Content $\mathbf{m g} / \mathbf{L}$ & Average OD & Content $\mathbf{~ m g / L ~}$ \\
\hline CX-7 & 0.120 & 5.18 & 2.710 & 71.60 & 0.029 & 3.44 \\
AC10012 & 0.221 & 3.83 & 46.06 & 0.013 & 1.50 & 1.50 \\
\hline
\end{tabular}

as Paenibacillus kribbensis, which was named CX-7.

\section{The ability of solubilizing phosphate and potassium}

The soluble phosphorus content in the broth was 5.18 and $71.60 \mathrm{mg} / \mathrm{L}$ respectively in the organic phosphate solubilization medium and inorganic phosphate solubilization medium by the methods of molybdenum antimony anti-colorimetry.

The soluble potassium content in the broth was 3.44 $\mathrm{mg} / \mathrm{L}$ potassium solubilization medium by the methods of tetraphenylboron sodium colorimetric.

The ability of solubilizing organic phosphate, inorganic phosphate and feldspar in powder in contrast with that of AC10012 strain; 3.83, 46.06, $1.50 \mathrm{mg} / \mathrm{L}$ respectively. It was lower than that of CX-7 strain (Table 2). The content of organic phosphorus was increased by $35.2 \%$, inorganic phosphorus was increased by $55.4 \%$, and the potassium was increased by $129.3 \%$, which indicated that CX-7 was an effective stain on the solubilization of phosphorus and potassium.

\section{Antagonism effect against pathogenic microorganism}

CX-7 strain had antagonism effect against five pathogenic microorganism. The results can be seen in the Figure 4 . The CX-7 strain inhibition zone area against cotton yellow wilt pathogen, cotton wilt pathogen, wheat root rot diseases pathogen, wheat scab pathogens and Pestalotiopsis microspora were 298.43, 334.56, 278.89, 314.03 and $314.67 \mathrm{~mm}^{2}$ respectively which indicated that strain CX-7 had antagonistic activity to several 

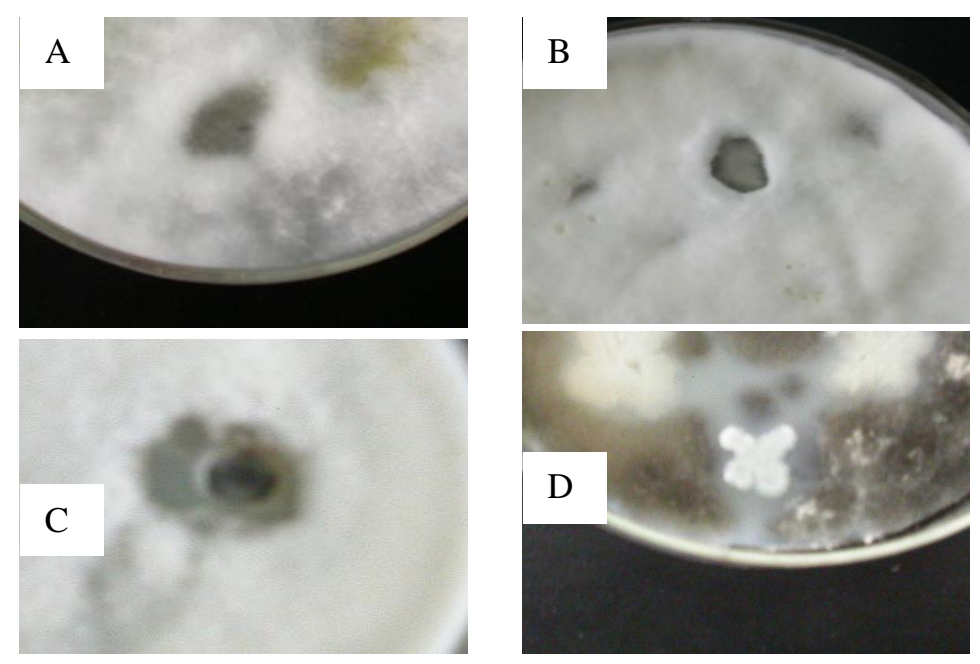

Figure 4. CX-7 strain antimicrobial spectrum. A, Wheat scab pathogens. B, Pestalotiopsis microspora. C, cotton wilt pathogen; D, wheat root rot diseases pathogen.

phytopathogenic fungi.

\section{Description of Paenibacillus kribbensis CX-7}

P. kribbensis CX-7 was isolated from the field of Chang'an, Shanxi province of China and preserved in the center of Hebei University, China. Cells were facultatively anaerobic rods with dimensions of $2.0-5.0 \mathrm{~mm}$ on isolation media. Gram-variable, ellipsoidal spores were formed in swollen sporangia motile by means of peritrichous flagella. Colonies were cream-coloured, circular to slightly irregular in shape, flat to low convex and translucent on isolation media. Optimal growth temperature was between 30 and $37^{\circ} \mathrm{C}$; growth occurred at 10 and $44^{\circ} \mathrm{C}$, but not at 4 or $45^{\circ} \mathrm{C}$. Optimal pH for growth was between $\mathrm{pH} 6.5$ and 8.0; growth was inhibited below $\mathrm{pH}$ 4.0. Growth was optimal in the presence of $0-2 \%(\mathrm{w} / \mathrm{v}) \mathrm{NaCl}$; growth occurred in the presence of $4 \%$ $(\mathrm{w} / \mathrm{v}) \mathrm{NaCl}$, but not in the presence of $5 \%(\mathrm{w} / \mathrm{v}) \mathrm{NaCl}$. Catalase reaction was positive, and Oxidase and ureasereactions were negative. Gelatin and starch were hydrlysed. Nitrate was reduced to nitrite. L-Arabinose, glucose, mannitol, xylose, maltose, lactose, sucrose and fructose were utilized

Strain CX-7 had high activity of solubilizing inorganic phosphate, organic phosphate and feldspar powder. The content of organic phosphorus was increased by $35.2 \%$, inorganic phosphorus was increased by $55.4 \%$, and the potassium was increased by $129.3 \%$, which indicated that CX-7 was an efficient stain on the solubilization of inorganic phosphorus and potassium. The activity was higher than the control strain AC10012 and DMS6 and
DMS5 reported by Yan et al. (2009).

On the other hand, strain CX-7 had antagonistic activity to several phytopathogenic fungi including cotton yellow wilt pathogen, cotton wilt pathogen, wheat root rot diseases pathogen, wheat scab pathogens and Pestalotiopsis microspora but strain POC 115 only had the ability against the dermatophyte fungus Trichophyton rubrum (Simone et al., 2012).

\section{Conclusion}

From the soil samples of wheat field in Chang'an, Shanxi, seven strains of silicate bacteria were isolated and the most efficient strain named $\mathrm{CX}-7$ was identified as $P$. kribbensis.

The solubilizing effect of inorganic phosphate, organic phosphate and feldspar powder by CX-7 strain was done via laboratory experiment. The ability of solubilizing phosphate and potassium was higher than that of reference strain AC10012.

CX-7 strain had antagonistic effect against many pathogenic microorganisms. The inhibition zone area against cotton yellow wilt pathogen, cotton wilt pathogen, wheat root rot diseases pathogen, wheat scab pathogens and P. microspora were 298.43, 334.56, 278.89, 314.03 and $314.67 \mathrm{~mm}^{2}$ respectively, which indicated that CX-7 has a widely effect against pathogenic microorganism. Not only the mineral phosphorus and potassium can be activated when inoculated with $P$. kribbensis CX-7, but also many plant pathogenic microorganisms can be inhibited. It was seldom reported in the domestic and foreign literature. But the basis of solubilizing phosphate 
and potassium and inhibiting pathogenic microorganism should be studied further.

\section{REFERENCES}

Alvarez VM, von der Weid I, Seldin L (2006). Influence of growth conditions on the production of extracellular proteolytic enzymes in Paenibacillus peoriae NRRL BD-62 and Paenibacillus polymyxa SCE2. Lett. Appl. Microbiol. 43:625-630.

Aperce CC, Burkey TE, KuKanich B (2010). Interaction of Bacillus species and Salmonella enterica serovar Typhimurium in immune or inflammatory signaling from swine intestinal epithelial cells. J. Anim. Sci. 88:1649-1656

Ash C, Priest FG, Collins MD (1993) Molecular identification of rRNA group 3 bacilli (Ash, Farrow, Wallbanks and Collins) using a PCR probe test. Antonie van Leeuwenhoek 64:253-260.

Bizani D, Brandcli A (2012) Characterization of a bacteriocin produced by a newly isolated Bacillus sp. Strain 8A. J. Appl. Microbiol. 93:512-519.

Buchanan JR, Gibbons NE (1974) Bergey's Manual of Determanation Bacteriology, $8^{\text {th }}$ ed., The Willianm and Wikins Company, Baltimore.

Dong XZ, Cai MY (2001). The Manual of Determinative Bacteriology. Beijing: Sciences Press, pp. 353-388.

Han L, Wang D, Lin RF (2011). Isolation and screening of antagonistic silicate bacterium. Chin. J. Soil Sci. 42(1):77-80.

Jing CL, Xu LH, (1997) Microbial Resource. Beijing: Science Press, p. 151.

Kumar S, Nei M, Dudley J, Tamura K (2008) MEGA: a biologist-centric software for evolutionary analysis of DNA and protein sequences. Brief Bioinform. 9:299-306

Massol-Deya AA, Odelson DA, Hickey RF (1995) Bacterial community fingerprinting ofamplified $16 \mathrm{~S}$ and $16-23 \mathrm{~S}$ ribosomal DNA gene sequences and restriction endonuclease analysis (ARDRA). In: Akkermans ADL, van Elsas JD, de Bruijn JF (eds), Molecular microbial ecology manual. Kluwer, The Netherlands. 3.3.2:1-8.

Olsen SR, Sommers LE (1982) Phosphorus. In: Page AL, editor. Methods of Soil Analysis: Chemical and Microbiological Properties. ASA and SSSA; Madison, WI, USA: pp. 403-430.

Peypoux F, Pommier MT, Das BC (1984) Structure of bacillomycin D and bacillomycin $L$ peptidolipid antibiotics from Bacillus subtilis. J. Antibiot. 37:1600-1604.

Podgorskii VS (1988). Leaching of silicon-containing rock using Bacillus mucilaginosus. Mikrobiologichesdii-zhurnal 50(5):25-30.

Rosado AS, Seldin L (1993) Production of a potentially novel antimicrobial substance by Bacillus Polymyxa. World J. Microbiol. Biotechnol. 90:521-528.
Ross N, Villemur R, Marcandella E (2001) Assessment of changes in biodiversity when a community of ultramicrobacteria isolated from groundwater is stimulated to form a biofilm. Microb. Ecol. 42:56-68.

Seldin L, Alviano CS (2010) Antimicrobial produced by Paenibacillus polymyxa, $P$. brasilensis and $P$. peoriae against microorganisms. In: De Araujo et al. (eds) Microbial ecology of tropical soils. Chapter 8. Nova Science Publishers, Inc., New York, pp. 157-166.

Seldin L, Dubnau D (1985) Deoxyribonucleic acid homology among Bacillus polymyxa, Bacillus macerans, Bacillus azotofixans, and other nitrogen-fixing Bacillus strains. Int. J. Syst. Evol. Microbiol. pp. 151-154.

Sheng XF, Huang WY, Cao XY (2001). Dissolution of feldspar and potassium uptake by the strain NBT of silicate bacterium. Plant Nutr. Fertilizer 7(4):459-466.

Simone RC, Fabia da Mota, Gleiser T (2012). Antimicrobial activity of Paenibacillus kribbensis POC105 against the determatophyte Trichophyto rubrum. World J. Microbiol. Biotechnol. 28:953-962.

Sun DS, Zhang Q (2006). Screening of silicate bacteria and bio-leaching silicon from silicate ores, J. Xi'an Univ. Sci. Technol. 26(2):235-239.

Tang L, Zhang JZ (2008). Isolation, purification and identification of silicate-dissolving bacterial strains and studies of their biological characteristics. Shandong Agric. Sci. 1:71-73.

Thompson JD, Higgins DG, Gibson TJ (1994). CLUSTAL W: improving the sensitivity of progressive multiple sequence alignment through sequence weighting, position-specific gap penalties and weight matrix choice. Nucleic Acids Res. 22:4673-4680.

Welch SA, Barker WW, Banfield JF (1999). Microbial extracellular polysaccharides and plagioclase dissolution. Geochimica et Cosmochimica Acta 63(9):1405-1419.

Welch SA, Ullman WJ (1993).The effect of organic acids on plagioclase dissolution rates and stoichimetry. Geochimica et Cosmochimica Acta 57(12):2725-2736.

Xu DY, Li F, He XL (2007). Isolation of silicate bacteria and their capability of releasing potassium. J. Huaibei Coal Ind. Teachers Coll. 270:42-44.

Yan XH, Zhao H, Zhu SF, Xue YH, Xu XK, Wang DH (2009). Study on abilities of 6 strains of silicated bacteria to release phosphorus and potassium. J. Anhui Agric. Sci. 37(28):13728-13729.

Zhang DL, Zuo JL (2000) Contrast analysis on determination of inorganic element $\mathrm{K}$ with flare photometer and sodium tetraphenylboron. Jingxi For. Sci. Technol. 5:26-28. 